\title{
Capital Structure, Business Risk and Corporate Performance (Case Study on Construction and Real Estate Sector)
}

\author{
Sutrisno* \\ Universitas Islam Indonesia, Indonesia
}

The purpose of this study is to examine the effect of capital structure and business risk on corporate performance. This study also examined the effect of non debt tax shield (NDTS) and sales growth (SG) on corporate performance with firm size (SIZ) as a control variable. Corporate performance is measured by return on assets (ROA), while capital structure is measured by debt to equity ratio (DER), and business risk meausred by degree of operating leverage (DOL). The population in this study is a company engaged in the construction and real estate sector that listed on the Indonesia Stock Exchange. The samples taken were 32 companies with purposive samp ling. observations period for 3 years (2015-2017). Data is processed using ordinary least square (OLS). The results showed on the significance level 0.10 , capital structure (DER) had a significant but negative effect on corporate performance. Business risk (DOL) and sales growth (SG) have a significant and positive effect on performance. While non debt tax shield (NDTS) and firm size (SIZ) have no significant effect on corporate performance 


\section{BACKGROUND}

The task of the financial manager is to find sources of funds with low costs and optimal composition and invest these funds in profitable assets in the future. Company management is demanded to be able to increase company value through increasing company performance.

Capital structure is the composition of total debt and equity Horne and Wachowicz (2015) . The larger the capital structure the greater the amount of debt, so the financial risk is higher, because the debt provides a fixed burden of interest. According to bankruptcy theory, the higher the debt, the worse the company, according to Modigliani and Miller (1958) if there is a tax on capital structure, it will increase the value of the company. Research on the relationship of capital structure with company performance is still not strong, because the results have not been consistent. The results of research by Basit and Irwan (2017), Saputra et al. (2015), Akeem et al. (2014), Data et al. (2017), and Cole et al. (2015) show that the capital structure has a significant and negative effect on firm performance. Whereas Juwita (2018) and Bashir et al. (2013) found the capital structure had a significant and positive effect on company performance, while Dada and Ghazal (2016) found a nonsignificant effect of capital structure on the performance of the company.

Every business must be risky. As a high risk, the higher the level of profit. Business risk is measured by degree of operating leverage (DOL), which is the level of sensitivity of earnings (EBIT) due to changes in sales. The higher the DOL, the higher the coefficient of risk and profit. Bashir et al. (2013), Ozturk et al. (2016), Florio and Leoni (2017), and Data et al. (2017) found a significant and positive influence between business risk and financial performance. The findings are different by Vakilifard and Oskouei (2014) who found sig nificant and negative effects between business risk and performance, while Alawattegama (2018) found that business risk had no effect on company performance.

Company profitability can be obtained from tax savings. Tax savings can be obtained from debt tax shiled in the form of interest and can come from non debt tax shields, namely depreciation. Depresaisi timbil because the company uses fixed assets. The higher the depreciation, the higher the tax value, so that it can improve the company's profitability. The results of Vinasithamby (2015) found that NDTS did not affect company performance, Bashir et al. (2013) in Pakistan, Sritharan (2015) in Sri Lanka and Suratno et al. (2017) found a positive and significant influence between NDTS and company performance.

One indicator of the success of management is that companies are able to grow into large companies. Companies can grow if they are able to generate profits, and the profits are reinvested, so they can generate additional profits. Sales growth is one of the benchmarks that the company's products are accepted by society. The higher sales growth will be able to generate profits so that it can increase the profitability of the company. Research Dada and Ghazal (2016), Maggina and Tsaklanganos (2012), Juwita (2018) and Odalo et al. (2016) found a positive and significant influence between sales growers and company performance, while Coban (2014) found insignificant influence between sales growth with company perfor- mance.

\section{THEORETICAL REVIEW AND HIPOTHESES}

\section{Capital Structure and Corporate Performance}

The source of corporate funds comes from two parties, from the owner referred to as equity and from creditors referred to as debt. The balance of the amount of debt with equity is called the capital structure Horne and Wachowicz (2015). Each funding source has different characteristics. Debt has a higher risk because the company must pay interest regularly even though the company is in a loss condition, while equity pay dividends if the company profits, according to Modigliani and Miller (1958) if there is a tax, the capital structure can increase the value of the company, but according to the trade-off theory, if the company needs additional funds, use retained earnings first and own capital, however, if the amount of debt is high, it will endanger the company, so that it will reduce the company's profits because they have to bear high interest costs, and will reduce profits. Results of research by Basit and Irwan (2017) in Malaysia, Saputra et al. (2015) in Indonesia showed a significant and negative influence between mo structure dal with company performance as measured by return on assets (ROA). Likewise with the research of Akeem et al. (2014) in Nigeria, Data et al. (2017) in Indonesia, and Cole et al. (2015) in the United States also found that the capital structure had a significant and negative effect on capital structure. This means that the greater the composition of debt to capital, the lower corporate performance.

H 1 : Capital structure (DER) has a negative effect on corporate performance (ROA)

\section{Business Risk and Corporate Performance}

In financial management, it is known as axioma risk and return, meaning that every action taken must contain a balanced risk and return. The higher the risk has a high profit potential. Business risk is the level of risk inherent in the operations of a company. Business risk consists of financial risk because using a source of funds comes from debt with the consequence of paying a fixed expense in the form of interest, and operating risk due to using fixed assets with the consequence of a fixed burden of depreciation. Operational risk is often measured by degree of operating leverage (DOL), which is a comparison between EBIT changes and sales activities (Vakilifard and Oskouei (2014) and Data et al. (2017)). The high DOL shows the high business risk of the company, but if sales increase it will increase the profitability of large keliptan. The results of the Bashir et al. (2013) study in Pakistan and Ozturk et al. (2016) in China, Turkey, India. Florio and Leoni (2017) Italy and Data et al. (2017) in Indonesia found significant and positive influences between business risk with corporate performance.

H 2 : Business risk (DOL) has a positive effect on corporate performance $(R O A)$ 


\section{Non Debt Tax Shield and Corporate Performance}

Tax is a burden that must be paid to the government in accordance with applicable regulations. There are two aspects that can reduce taxes, first the amount of debt (debt tax shield) and open from debt (non debt tax shield). Tax protection comes from debt due to interest as a tax deduction, while those from NDTS are from the amount of depreciation. Depreciation is a non-cash expense, meaning that the depreciation is treated as a fee but is not covered in cash. Costs will reduce taxes, so the greater the depreciation, the less tax will be deducted and will increase profits. Thus the magnitude of NDTS is able to improve productivity. The results of the Bashir et al. (2013) study in Pakistan and Sritharan (2015) in Sri Langka showed that NDTS had a significant effect on company performance, while Suratno et al. (2017) found NDTS had an effect on company performance through capital structure.

H 3 : Non debt tax shield (NDTS) has a positive effect on corporate performance (ROA)

\section{Sales Growth and Corporate Performance}

Companies that perform well are characterized by the company's growth. The high growth of the company shows the ability of the company's effectiveness and efficiency in managing its resources Saputra et al. (2015). Company growth can be measured by sales growth from year to year (Akeem et al. (2014) and

Coban (2014) ). The higher sales growth indicates the company is growing. With high sales growth, it is expected that it will be able to increase the company's profits which will ultimately improve the company's performance. The results of Dada and Ghazal (2016), Maggina and Tsaklanganos (2012), Juwita (2018) and Odalo et al. (2016) found a positive influence between the growth of companies and corporate performance.

H 4 : Sales growth (SG) has a negative influence on corporate performance (ROA)

\section{RESEARCH METHODS}

\section{Population and Sample}

The population in this research is companies listed on the Indonesia Stock Exchange in the construction, property and real estate sectors. The samples taken were 24 companies using the purposive sampling method, with an observation period of 4 years (2014-2017).

\section{Variable Definition}

The research variable consisted of one dependent variable namely corporate performance as measured by return on assets, and four independent variables consisting of capital structure (DER), business risk (DOL), non debt tax shield (NDTS) and sales growth (SG). This study uses a company size control variable (SIZ). Next is the variable measurement variable.

[Table 1 about here.]

\section{DATA ANALYSIS}

To test the hypothesis, multiple regression analysis will be used using a significance level of 0.05 . Following are the regression equations:

$\mathrm{ROA}=\alpha+\beta_{1} \mathrm{DER}+\beta_{2} \mathrm{DOL}+\beta_{3} \mathrm{NDTS}+\beta_{4} \mathrm{SG}+\beta_{5}$ $\mathrm{SIZ}+\varepsilon$

Keterangan:

ROA : return on assets

DER : debt to equity ratio

DOL : degree of operating leverage

NDTS : non debt tax shield

SG : sales growth

SIZ ; firm size

\section{RESULTS AND DISCUSSION}

\section{Descriptive Statistics}

To find out the description of the data, the following are the results of descriptive statistics from research data:

[Table 2 about here.]

Based on the table above, it is known that the corporate performance variable (ROA) shows a maximum value of $41 \%$ and a minimum value of $-25 \%$ with an average of $5.18 \%$. capital structure (DER) has the highest value of 3.83 times and a minimum of 0.04 times with an average of 1.04 times, meaning that the average corporate debt is greater than the equity. Business risk (DOL) with a maximum value of 38.67 and a minimum of -68.98 with an average of 0.69 . While the non debt tax shield (NDTS) has a maximum value of $0.08 \%$ and a minimum value of $0.00 \%$ with an average of $0.01 \%$.

\section{Hypothesis Test Results}

Hypothesis testing using a multiple regression analysis tool assisted with SPSS version 21.0 data programming obtained the following hypothesis test results:

\section{[Table 3 about here.]}

Based on the results of hypothesis testing as in table 3 above, it shows that with a significance level of 0.10 , the capital structure as measured by the debt to equity ratio (DER is significant efeect but negative to corporate performance. Business risk as measured by degree of operating leverage (DOL) sales growth (SG) has a significant and positive effect on corporate performance, while non-debt tax shield (NDTS) and company size (SIZ) have no significant effect on corporate performance.

Capital structure has a significant and negative effect on corporate performance, meaning that the higher the capital structure the lower the company's performance. This result is due to the average capital structure of 1.04 , which means that the total debt held by the company is on average greater than the equity. If seen from the average ROA, it is $5.18 \%$, which is likely to be smaller than the interest rate, so the selection of sources of funds from debt is not quite right. This result is in accordance with the bankruptcy theory that the higher the debt, the higher the risk of bankruptcy. Basit and Irwan (2017), Saputra et al. (2015) found a significant and 
negative effect between capital structure and company performance. Akeem et al. (2014) in Nigeria, Data et al. (2017), and Cole et al. (2015) also found the effect of capital structure on company performance.

Business risk variables hypothesized to have a positive effect on performance were not proven. Research results show that business risk does not affect the company's performance. This is probably due to the company's sample data having an average business risk that is very small at $0.65 \%$, meaning that the average sample company does not dare to take high risks so it cannot increase profitability. Whereas according to Data et al. (2017) and Florio and Leoni (2017) there is a significant and positive influence between business risk and company performance. However, this result was supported by Alawattegama (2018) who conducted research in Sri Lanka and found that business risks did not affect the company's performance. Vakilifard and Oskouei (2014) found a significant but negative influence between business risk and the performance of an automotive company in Tehran.

Non debt tax shields (NDTS) statistically have no significant effect on company performance. NDTS shows the amount of depreciation funds set aside each year. NDTS in sample companies is a very small average of $0.6 \%$. The small number of NDTS is likely to cause NDTS to be unable to influence company performance. NDTS is expected to be able to reduce taxes, the higher the NDTS the more tax the company can save. However, if the number of NDTS is small, the tax protection is not able to encourage increased profitability so it does not affect the company's performance. The results of the study were supported by Vinasithamby (2015) who found an insignificant influence between NDTS and company performance. But it contradicts Bashir et al. (2013), Suratno et al.
(2017), and Sritharan (2015) who find a significant influence between NDTS and company performance.

Sales growth shows the success of company management in maintaining and increasing customers. Customer growth also shows that the product produced by the company is favored by customers so that there are many loyal customers and new customers. Company profits are obtained because of sales, so that higher sales will have the potential to increase sales. In the sample companies the average growth of the company is quite high at $9.24 \%$, meaning that this growth means that it can increase profitability. Juwita (2018) who conducted research in Indonesia also found that sales growth was able to improve company performance. While Maggina and Tsaklanganos (2012) found that company growth as measured by asset growth also affected the company's performance. Odalo et al. (2016)

\section{CONCLUSSION}

Based on the results of hypothesis testing and discussion it can be concluded that there are two hypotheses which are proven, namely the capital structure has a negative effect on corporate performance and sales growth has a significant and positive effect on corporate performance. While two hypotheses are not proven namely business risk and non debt tax shield (NDTS) which have no significant effect on corporate performance.

From the results of these conclusions can be suggested that the company in using debt must be careful, because the amount of debt shown by the capital structure has a negative effect on company performance. Also need to increase sales so that sales growth gets higher with the hope that the high sales growth will improve corporate performance

\section{REFERENCES}

Akeem, L. B., Terer, E., Kiyanjui, M., and Kayode, A. M. (2014). Effects of Capital Structure on Firms Performance: Empirical Study of Manufacturing Companies in Nigeria. Journal of Finance and Investment Analysis 3, 39-57.

Alawattegama, K. K. (2018). The Effect of Enterprise Risk Management (ERM) on Firm Performance: Evidence from the Diversified Industry of Sri Lanka. Journal of Management Research 10, 75-84.

Bashir, Z., Abbas, A., Manzoor, S., and Akram, M. (2013). Empirical Investigation of the Factors Affecting Firms Performance: a Study Based on Food Sector of Pakistan. International SAMANM Journal of Finance and Accounting 1, 11-24.

Basit, A. and Irwan, N. F. (2017). The Impact of Capital Structure on Firms Performance: Evidence from Malaysian Industrial Sector: A Case Based Approach International Journal of Accounting \& Business Management 5, 131-148.

Coban, S. (2014). The Interaction Between Firm Growth and Profitability: Evidence from Turkish (Listed) Manufacturing Firms. The Journal of Knowledge Economy \& Knowledge Management 9, 73-82.

Cole, C., Yan, Y., and Hemley, D. (2015). Does Capital Structure Impact Firm Performance: An Empirical Study of Three U.S. Sectors. Journal of Accounting and Finance 15.

Dada, A. O. and Ghazal, Z. B. (2016). The Impact of Capital Structure on Firm Performance: Empirical Evidence from Nigeria. Journal of Economics and Finance, $33-63$

Data, A., Alhabsji, T., Rahayu, S., and Handayanis, R. (2017). Effect of Growth, Liquidity, Business Risk and Asset Usage Activity, Toward Capital Structure, Financial Performance and Corporate Value (Study at Manufacturing Companies Listed in Indonesia Stock Exchange in 2010-2015). European Journal of Business and Management 9, 9-26.

Florio, C. and Leoni, G. (2017). Enterprise risk management and firm performance: The Italian case. The British Accounting Review 49, 56-74.

Horne, J. V. and Wachowicz, J. M. (2015). 13th Ed.

Juwita, A. (2018). The Effect Of Capital Structure, Liquidity, And Growth On Corporate Performance Classified As Small Capitalization Companies On Indonesia

Stock Exchange Period 2011-2016. International Journal of Scientific \& Technology Research 7, 76-81.

Maggina, A. and Tsaklanganos, A. (2012). Asset Growth And Firm Performance Evidence From Greece. The International Journal of Business and Finance Research $6,113-125$.

Modigliani, F. and Miller, M. H. (1958). The Cost of Capital, Corporation Finance and the Theory of Investment 48, 261-297.

Odalo, S. K., Njuguna, A., and Achoki, G. (2016). Relating Sales Growth And Financial Performance In Agricultural Firms Listed In The Nairobi Securities Exchange In Kenya. International Journal of Economics 4, 443-455. Commerce and Management.

Ozturk, M. B., Sahin, E., and Actan, G. C. (2016). Relationship Between Financial Risk And Business Risk With Firm Values In The Logistics Industry: An Analysis On Brics-T Countries. Int. Journal of Management Economics and Business 16, 532-547. Special Issue.

Saputra, T., Achsani, N., and Anggraeni, L. (2015). The Effect of Capital Structure on Firm Performance: Empirical Evidence from the Indonesian Financial Industry. International Journal of Business and Management Invention 4, 57-66.

Sritharan, V. (2015). Do tax shields of debt and non debt impact on firms' performance? Evidence from Sri Lankan Land and property sector. Research Journal on Economics \& Business Studies 4, 10-22.

Suratno, Djaddang, S., and Ghozali, I. (2017). The Role of Business Risk and Non Debt Tax Shields to Debt to Equity Ratio on Pharmacy Listed Companies in Indonesia. International Journal of Economics and Financial 7, 73-80.

Vakilifard, H. and Oskouei, M. M. (2014). The Effect of Risk on Firm Performance: Evidence from Automobile Companies Listed in Tehran Stock Exchange (TSE). Middle-East Journal of Scientific Research 19, 740-746.

Vinasithamby, S. (2015). Do tax shields of debt and non debt impact on firms performance? Evidence from Sri Lankan Land and property sector. Research Journal of Economic and Business Studies 4, 10-22.

Conflict of Interest Statement: The author declare that the research was conducted in the absence of any commercial or financial relationships that could be construed 
as a potential conflict of interest.

Copyright (c) 2019 Author. This is an open-access article distributed under the term of the Creative Commons Attribution License (CC BY). The use, distribution or repro- duction in other forums is permitted, provided the original author(s) and the copyright owner(s) are credited and that the original publication in this journal is cited, in accordance with accepted academic practice. No use, distribution or reproduction is permitted which does not comply with these terms. 


\section{LIST OF TABLES}

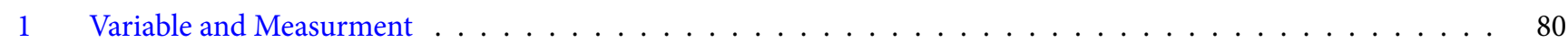

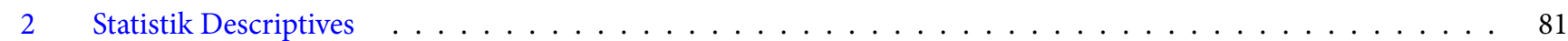

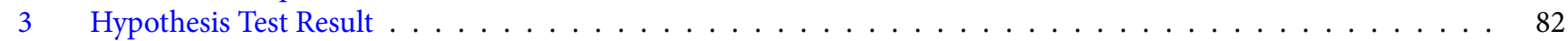


TABLE 1 | Variable and Measurment

\begin{tabular}{lll}
\hline Table 1 & & \\
Variable & Notation & Measurement \\
Corporate Performance & ROA & EAT/Total Assets \\
Capital Structure & DER & Total Debt/Equity \\
Business Risk & DOL & $\Delta$ EBIT/ $\Delta$ Sales \\
Non Debt Tax Shield & NDTS & Depreciation/Total Assets $_{\text {Sales Growth }}$ \\
Firm Size & SG & $\left(\right.$ Sales $_{t}-$ Sales $\left._{t-1}\right) /$ Sales $_{t-1}$ \\
\hline
\end{tabular}


TABLE 2 | Statistik Descriptives

\begin{tabular}{llllll}
\hline Table 2 & & & & & \\
& N & Minimum & Maximum & Mean & Std. Deviation \\
ROA & 96 & -.25 & .41 & .0518 & .07658 \\
DER & 96 & .04 & 3.83 & 1.0352 & .80353 \\
DOL & 96 & -68.98 & 38.67 & .6580 & 10.50341 \\
NDTS & 96 & .00 & .08 & .0069 & .01056 \\
SG & 96 & -1.00 & 4.37 & .0924 & .56075 \\
SIZ & 96 & 21.77 & 31.75 & 28.4076 & 2.63737 \\
\hline Valid N (listwise) & 96 & & & \\
\hline
\end{tabular}


TABLE 3 | Hypothesis Test Result

\begin{tabular}{|c|c|c|c|c|c|c|}
\hline \multicolumn{7}{|c|}{ Table 3} \\
\hline \multirow{2}{*}{\multicolumn{2}{|c|}{ Model }} & \multicolumn{2}{|c|}{$\begin{array}{l}\text { Unstandardized } \\
\text { Coefficients }\end{array}$} & \multirow{2}{*}{$\begin{array}{l}\text { Standardized Coefficients } \\
\text { Beta }\end{array}$} & \multirow[t]{2}{*}{$\mathbf{t}$} & \multirow[t]{2}{*}{ Sig. } \\
\hline & & B & Std. Error & & & \\
\hline \multirow{6}{*}{1} & (Constant) & .049 & .077 & & .631 & .530 \\
\hline & DER & -.016 & .009 & -.163 & -1.707 & .091 \\
\hline & DOL & .001 & .001 & .164 & 1.729 & .087 \\
\hline & NDTS & -.213 & .684 & -.029 & -.311 & .757 \\
\hline & SG & .056 & .013 & .412 & 4.363 & .000 \\
\hline & SIZ & .001 & .003 & .018 & .186 & .853 \\
\hline
\end{tabular}

